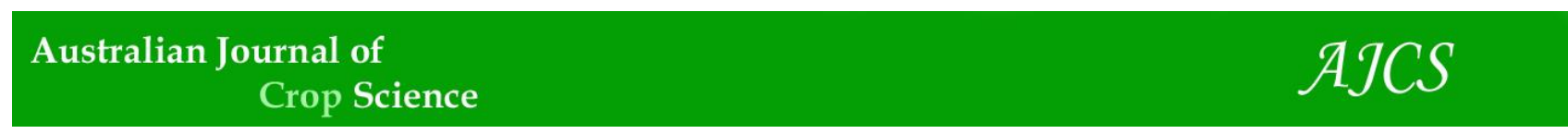

AJCS 10(12):1635-1639 (2016)

ISSN:1835-2707

doi: 10.21475/ajcs.2016.10.12.PNE225

\title{
Carbohydrate levels in 'douradão' peach tree grown under subtropical conditions
}

\author{
Bruno Henrique Leite Gonçalves, Sarita Leonel, Jackson Mirellys Azevêdo Souza, Marco Antonio \\ Tecchio, Lucas Lencione Arruda, Marcelo de Souza Silva
}

\author{
Department of Horticulture, Universidade Estadual Paulista (UNESP), Botucatu, Brazil
}

\section{*Corresponding author: bruno_lleite@hotmail.com}

\begin{abstract}
Most studies ignored the translocation of carbohydrates in peach tree at different stages of growth, particularly under subtropical conditions that might affect the phenological cycle. Therefore, the present study aimed to evaluate the carbohydrate levels in 'Douradão' peach when cultivated under subtropical condition. In field, peach trees were two years old, spacing of $6.0 \mathrm{x} 4.0 \mathrm{~m}$. The experiment design was randomized blocks, consisting of 3 plants per plot and 4 repetitions. Each of the following: roots, branches, leaves and fruits were separately done by ANOVA, since they were all collected at different periods. Leaves and branches samples were collected at different time periods, such as January, February, March, April, May, July, August, September, October and December. Root samples were collected in January, April, August, November and December. In November, fruits were collected whether 4 fruits per plant met the minimum Brix value of $10^{\circ}$. During the annual cycle, there were significant variations of carbohydrate levels in leaves, branches and roots. Thus, starch is the most common form of carbohydrate in trees, wherefore the highest levels was obtained in June, when leaves fall naturally.
\end{abstract}

Keywords: fruit; photoassimilates; Prunus persica L.; starch; sugars.

Abbreviations: CHO_Carbohydrate; HCl_Hydrochloric acid; SS_Soluble sugars; ST_starch; SC_ Sucrose; TS_ Total sugar.

\section{Introduction}

Peach trees have become an important option for diversifying agricultural products, especially for small producers and family farms in the state of São Paulo, Brazil. Commercial peach production was only possible through improvements in materials and cultivars that have been adapted to mild winter climatic conditions (Pedro Júnior et al., 2007) by the Agronomic Institute of Campinas.

The greatest advantage of São Paulo is that the fruit production presented an early harvest, compared with other major producers from the same country and other SouthAmerican countries, such as Chile, Argentina and Uruguay (Leonel et al., 2011). In other words, this precocity is due to weather conditions and cultivars adapted to subtropical climate. Sao Paulo leads fresh peach produce consumption. Therefore, the quality of the fruit is a crucial requirement in order to achieve a better market price to gain more consumers; consequently, higher income to the producer. In São Paulo, peach crop obtained an increase in the production by using appropriate techniques, plant growth regulators and cultivars grown in less-demanding climates.

The growth of peach tree is limited under inappropriate climatic conditions, enabling them to survive on water scarcity or low temperatures, i.e. their dormant period. In this stage, essential metabolic activities continue, although reduced-intensity (Petri et al., 1996).

Both intrinsic and extrinsic factors are related to the beginning of the dormancy period, such as $\mathrm{CHO}$ translocation. In the Rosaceae family, carbons are mostly stored in the form of ST in the chloroplast during photosynthesis; or transferred to cytosol to be converted in soluble CHO, SC and sorbitol (Carvalho \& Zanette, 2004).
According to Araújo et al. (2008), there may be a competition for photoassimilates between vegetative growth and flowering buds, since these events occur at the same time in peaches.

Many researches aimed at improving directly or indirectly the quality of fruit based on the use of reserves; between the demand of soluble solids and reserve tissues; and organs of the plants that produce $\mathrm{CHO}$ (Araujo et al., 2008). CHO storage is essential in supporting plant growth during periods of stress; dormancy; and between vegetative development and fruiting. Thus, peach trees need $\mathrm{CHO}$ reserves, as it encourages flowering in the subsequent year, even as the development of quality fruits. It is also worth considering how the reserve of peach would be mobilized under subtropical conditions, since the majority of studies have been conducted under temperate climate, i.e. cold winters and low temperatures.

$\mathrm{CHO}$ content of different plant organs at different time periods during the annual cycle, associated with plant physiology can ensure good agricultural practices throughout the year. Given all the above, this study aimed to determine the content of CHO during the annual cycle of 'Douradão' peach grown under subtropical conditions in Botucatu, São Paulo, Brazil.

Results and discussion

Carbohydrate level in roots

$\mathrm{CHO}$ levels underwent variations at different time periods during the annual cycle of 'Douradão' peach tree (Fig 2-A, 2- 
Table 1. Percentage (mg.100 $\mathrm{mL}^{-1}$ ) of soluble sugars (SS), sucrose (SC) and total sugars (TS) in the fruits of the peach tree cv. Douradão FCA/UNESP/Botucatu-SP, 2012.

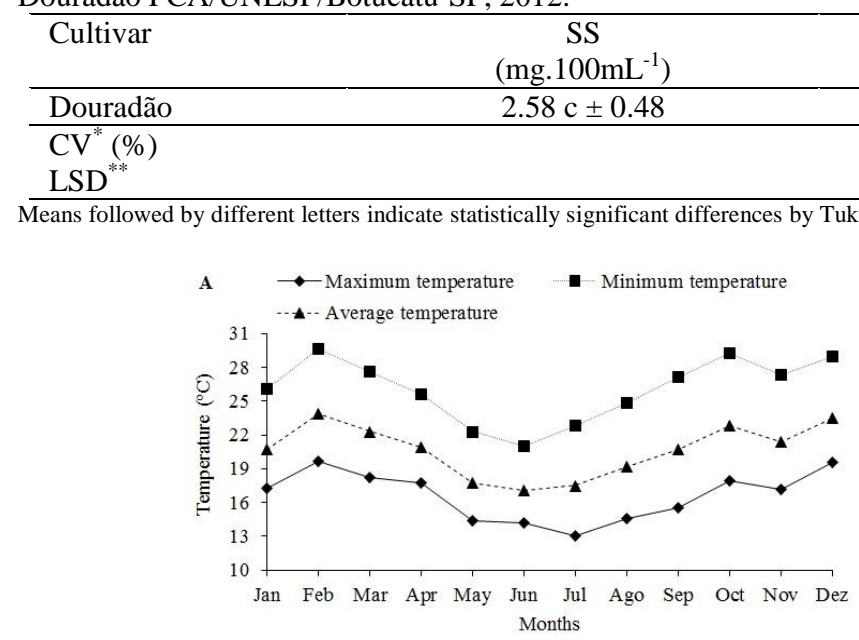

\begin{tabular}{|c|c|}
\hline $\begin{array}{c}\mathrm{SC} \\
\left(\mathrm{mg} .100 \mathrm{~mL}^{-1}\right)\end{array}$ & $\begin{array}{c}\mathrm{TS} \\
\left(\mathrm{mg} .100 \mathrm{~mL}^{-1}\right)\end{array}$ \\
\hline $5.36 \mathrm{~b} \pm 0.85$ & $8.23 \mathrm{a} \pm 0.79$ \\
\hline $\begin{array}{c}11.64 \\
1.36\end{array}$ & \\
\hline
\end{tabular}

Fig 1. Average maximum and minimum temperatures (A); and monthly rainfall (B); of Lageado Experimental Farm, FCA/UNESP,

Botucatu, SP, 2012.
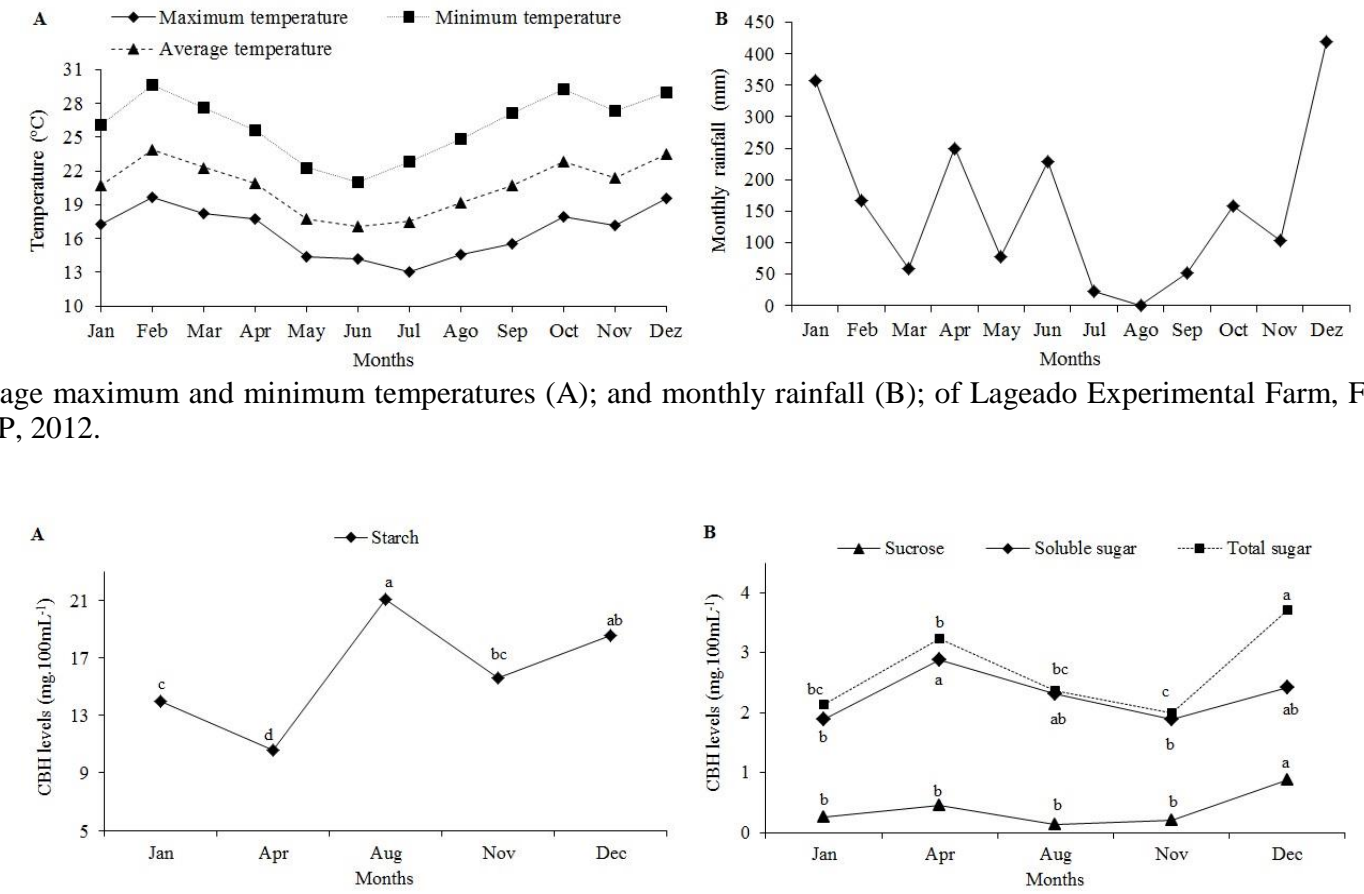

Fig 2. Starch average levels (A); soluble sugars, sucrose and total sugars (B), in roots of the 'Douradão' cultivar of different sampling time periods. Botucatu. SP, 2012. Means followed by same letters, for each carbohydrate, do not indicate statistically significant differences by Tukey test at $5 \%$.
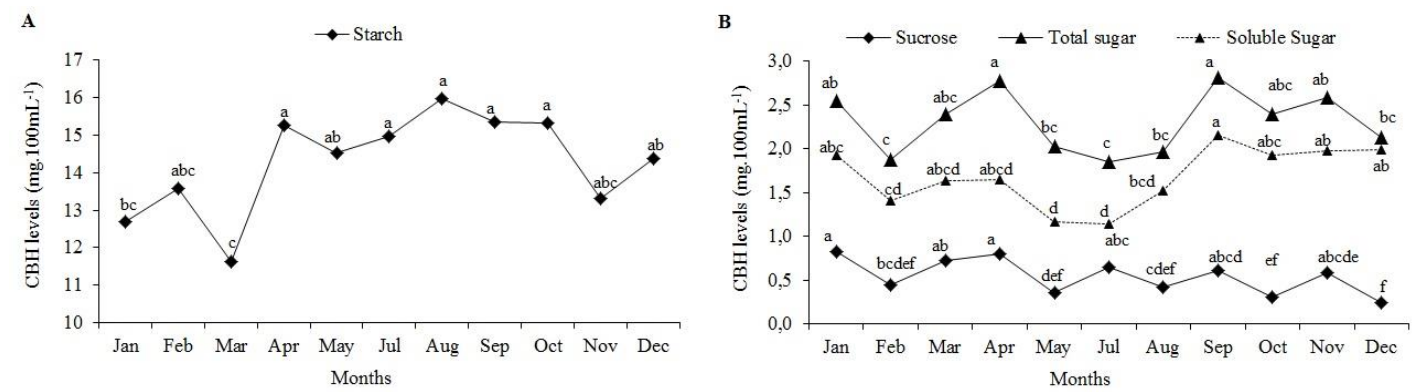

Fig 3. Starch Average levels (A); total sugars, sucrose and soluble sugars (B), in branches of the 'Douradão' cultivar of different sampling time periods. Botucatu, SP. 2012. Means followed by same letters, for each carbohydrate, do not indicate statistically significant differences by Tukey test at $5 \%$.
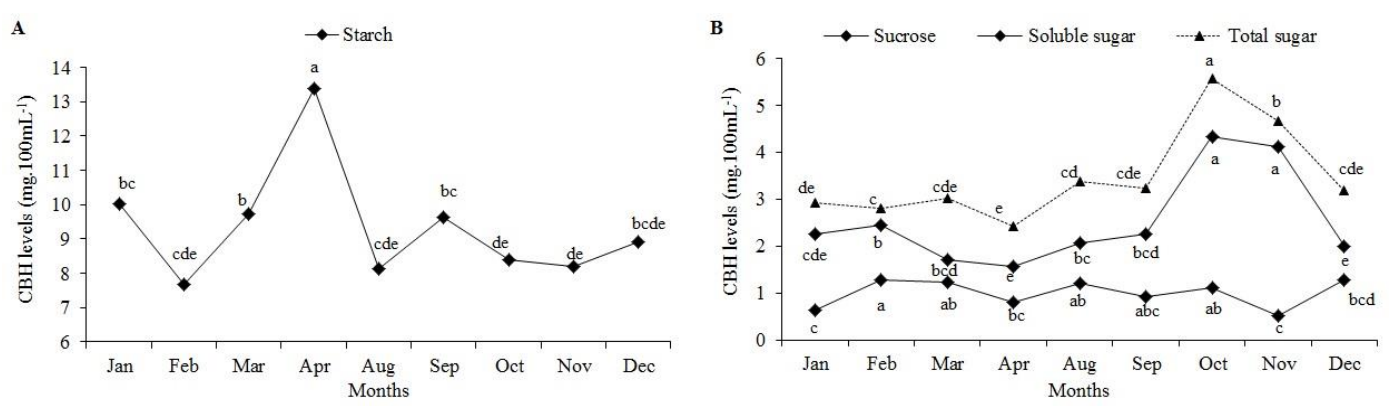

Fig 4. Starch average levels (A), total sugars, sucrose and soluble sugars (B); in leaves of the 'Douradão' cultivar of different sampling time periods. Botucatu, SP. 2012. Means followed by same letters, for each carbohydrate, do not indicate statistically significant differences by Tukey test at $5 \%$. 
B, 3-A, 3-B, 4-A, 4-B). Thus, ST content in root was higher than in branches most of the time; except in April, when the ST content was higher in leaves (Fig 2-A, 2-B, 3-A, 3-B).

In deciduous plants, accumulation of chilling hours is required in order to break dormancy, depending on each species and cultivar. Dormancy can trigger $\mathrm{CHO}$ levels, as there is a decrease in temperature; $\mathrm{CHO}$ availability is also associated to growing season, flowering and fruiting.

After the trees were pruned in January; there was a significant decrease in ST levels, being the lowest one observed in April, because the starch stored in roots was translocated to the aerial part. This result corroborates with the one by Borba et al. (2005), who also reported a decrease in $\mathrm{CHO}$ levels in April by pruning peach trees in the early year.

$\mathrm{CHO}$ plays a major role in the regulation of protein and lipid, even as other secondary metabolites, i.e. cellulose and flavonoid biosynthesis, because genes and proteins were involved in $\mathrm{CHO}$ metabolism, such as the tricarboxylic acid cycle (Hua et al., 2007; Noguchi et al., 2009, Li et al., 2011). The highest values were observed in August and December. August coincides with the end of dormancy; therefore, the beginning of budding, flowering, and the peak cycle storage with $19.48 \mathrm{mg}$ of ST $\left(100 \mathrm{~mL}^{-1}\right)$. During dormancy, carbohydrates are stored in branches and roots, because the capacity of shoot apical meristem to reverse sugars is reduced; therefore increasing ST hydrolysis to protect the plant against low temperatures. By the time that fruits ripen in November, there was a redistribution of photoassimilates; consequently, decreased in levels (Figure 2-A). This was also reported by Hidalgo (1993), while evaluating vine, it was observed that these reserves were used for processes that required energy, such as budding; the growth of the branches; flowering and fruiting.

SC levels varied during all the evaluated period, presenting a significant increase in December (Figure 2-B), i.e. after harvesting in November, when the aerial parts of the plants were full developed, thus translocating NSS and SS, followed by $\mathrm{CHO}$ storage until February-March.

\section{Carbohydrate level in branches}

In non-photosynthesizing organs, $\mathrm{CHO}$ storage provides the energy needed to start budding, flowering and fruiting. According to Borba et al. (2005), the potential of peaches production in a cycle is directly related with the reserves accumulated in previous cycle, being more visible in roots reserves than branches.

After the trees were pruned in January, TS underwent a significant decrease in branches (Figure 3-B). Therefore, affecting $\mathrm{CHO}$ storage in branches and leaves, thus requiring ST stored in the root system in order to meet the energy needed for the metabolism. From February onwards, photoassimilates were produced one more time, but there are no $\mathrm{CHO}$ reserves in the roots. From April onwards, the process of dormancy begins, as there was a decrease in TS levels, which were converted into other sugars. These data corroborates with that one obtained by Flore and Layne (1996), verifying a maximum value for CHO stored in branches at the middle of the dormancy, corresponding roughly to June-July in subtropical climate. Borba et al. (2005) also found higher soluble CHO levels in branches in July, i.e. during the middle of fruiting phase.

There were also variations in ST levels in the branches of peach tree, being the highest level of $16.1 \mathrm{mg}\left(100 \mathrm{~mL}^{-1}\right)$ obtained in April, as the CHO stored in roots was translocated after pruning, i.e. January, to develop the branches (Fig 3-B). Pruning caused significant variations in $\mathrm{CHO}$ levels in the aerial part, making an immediate translocation of the $\mathrm{CHO}$ stored in the roots to be used at the end of the dormant period. This has explained why Faust (1989) considered harmful for plant to be pruned during summer, as it causes an unbalance in $\mathrm{CHO}$ storage. The question arises whether new buds will be sufficient in the short-term to meet the plant energy needs or whether there will be a decrease in fruit production.

With regards to the SS, there were significant variations of most time periods. In November, there was a significant decrease compared with October (i.e. harvesting time), in other words, no translocation within the fruit (Figure 3-B).

From April onwards, there was a decrease in ST and SS levels in the branches (Figure 3-A), mainly caused by low temperatures and rainfall (Figures 1A-1B). At the beginning of flowering (i.e. in August), TS stored in the roots were translocated to the aerial part; which was necessary to meet the energy required for the initial growth of buds and flowers. At early stage, new leaves do not produce enough TS to meet their own metabolic needs in order to develop flower buds and fruits.

\section{Carbohydrate level in leaves}

In the state of São Paulo, after budding and leaf falling, there are two different stages of $\mathrm{CHO}$ levels in leaves (Figures 4-A and 4-B). The first stage happens as soon as the dormancy is broken (i.e. mid-July), when the development of the aerial part begins. Budding is responsible for all production and concentration of $\mathrm{CHO}$ stored during dormancy in nonphotosynthesizing organs; therefore, the supply of energy begin to develop the first leaves, as there are no leaves in peach trees to produce energy in this period; in other words, requiring cumulative concentration. The second stage is the translocation of carbohydrates produced in their leaves by photosynthesis, transporting them to branches and roots in the form of SS, especially NSS. This stage begins in midNovember (Figures 4-A and 4-B), and ends in May, when the plant becomes dormant again and leaves start to fall. In August, flowering period begins with an intense $\mathrm{CHO}$ consumption in order to form new vegetative and flowering buds; consequently, significant decrease in the leaf ST levels. In September (i.e. after abscission), a decrease in $\mathrm{CHO}$ depletion and hence an increase in the leaf ST levels (Figure 4-A); whose were transported from the roots or high photosynthesis rates probably due to the effect of high temperatures (Figure 1-A) and/or the beginning of summer (Pereira et al. 2011). During this whole experiment, the most common $\mathrm{CHO}$ found in roots, leaves and branches was ST. In these organs, the highest concentration of ST coincided with periods of low temperatures and dry season (Figure 1). According to Charkazi et al. (2010), cold, drought and salinity are among the plants major stress to accumulate $\mathrm{CHO}$.

\section{Carbohydrate level in fruits}

Ripen fruits presented higher levels of SS, TS and SC in November. There was a decrease in ST content in branches and roots, probably due to the conversion into SS, TS and $\mathrm{SC}$; in addition to be translocated within the growing fruits (Table 1). Borba et al. (2005) stated that the initial growth of fruit and branch takes place mainly at the expense of roots system, in other words, photoassimilates are mainly absorbed by young leaves and developing fruits. 
This has suggested that sugars availability in plant increases in the early stages of fruits development, thereby maintaining a high demand for photoassimilates, since they may require high amounts of energy in the period of cell division (Mehouachi et al. 2009). About sixty days from flowering associated to the higher demand of $\mathrm{CHO}$, the accumulation of TS was favored by the meteorological conditions, specially the increase in the average maximum and minimum temperatures (Fig. 1-A) since spring time, when plants presented an increase in the photosynthetic rates; consequently, an increase in the concentration of $\mathrm{CHO}$ in the leaves.

In 'Douradão' peach, the concentration of SS was higher than the ones obtained by Marafon et al. (2007), who reported a concentration of SS under subtropical conditions in Botucatu, SP, ranged from $1.59 \mathrm{mg} 100 \mathrm{~mL}^{-1}$ to $2.21 \mathrm{mg}$ $100 \mathrm{~mL}^{-1}$ with the highest values obtained in the genotypes Cascata 969, Cascata 848, Cascata 587, Precocinho, Diamante Mejorado and Oro Azteca.

In peaches, the concentration of SS (i.e. glucose + fructose)


varied from $4.9 \mathrm{mg} 100 \mathrm{~mL}^{-1}$ to $8.0 \mathrm{mg} 100 \mathrm{~mL}^{-1}$. These results are very close to those obtained by Chitarra and Carvalho (1985), who obtained $2.58 \mathrm{mg} 100 \mathrm{~mL}^{-1}$ of SS and $5.36 \mathrm{mg} 100 \mathrm{~mL}^{-1}$ of SC. The changes in $\mathrm{CHO}$ content are important because of their direct relationship with physiological processes, such as photosynthesis, respiration and translocation (Hasaneen and Younis, 2009).

In kiwi fruit, ST is most common form of accumulated $\mathrm{CHO}$ during fruit development. During harvesting, most of the $\mathrm{CHO}$ level is hydrolyzed into simple sugars in the ripening stage (Jordan et al.,2000; Atkinson \& Macrae, 2007). These differences between different sugars and ST at different stages of fruit development may be due to variations in the activities of invertase, sucrose synthase, hexokinase, fructokinase, and perhaps, sucrose-phosphate synthase among the species (Boldingh et al., 2000). Considerable changes in soluble sugar concentrations occur throughout the ripening stage of climacteric fruits, according to Chitarra and Chitarra (2005), this content continues increasing during postharvest and storage period, but decreasing in ripen fruits by the respiratory activity due to increased degradation of polysaccharides.

\section{Materials and Methods}

\section{Location and experimental area description}

The experiment was conducted in the Lageado Experimental Farm, Botucatu School of Agronomy, UNESP (22 $51^{\circ} 55^{\prime \prime S}$, $48^{\circ} 26^{\prime} 22^{\prime \prime} \mathrm{W} ; 810 \mathrm{~m} \mathrm{~m}$ altitude). According to Köppen's classification, the climate type is Cwa, i.e. mesothermal climate (dry winter/wet summer pattern associated with humid subtropical climate). The mean annual rainfall is 1433 mm (Cunha and Martins, 2009). In the Department of Natural Resources of the aforementioned university, a weather station collected all the respective data (Fig 1-A and 1-B).

\section{Plant materials and experimental design}

The experiment design was totally randomized, consisting of four plants per block and four repetitions. Each of the following: roots, branches, leaves and fruits were separately done by ANOVA, since they were all collected at different periods. During the annual cycle, treatments consisted of leaves and branches collection periods (i.e. January, February, March, April, May, July, August, September,
October, November and December, 2012); while roots sample was collected in January, April, August, November and December, 2012; and fruits in November, 2012.

The evaluation consisted of the 2 years old plants from 'Douradão' cultivar grafted onto Okinawa rootstock. 'Douradão' cultivar was launched in 1998 by Agronomic Institute of Campinas (IAC), which is a descendant of Golden -1 and presents vigor and compact growth. They are used in their natural or industrialized state. Additionally, ripening happens in mid-October. Moreover, this cultivar requires about 200 chill hours below $7.2^{\circ} \mathrm{C}$ to break the stage of dormancy (Barbosa et al, 2000).

The management practices were recommended by Scarpare Filho et al. (2003). Pruning and completely green replenishment was performed in January, 2012. Fruit tree pruning was performed on July $20^{\text {th }}$, 2012. After that, the pruned branches were brushed with Bordeaux mixture, which is a combination of copper sulfate, lime and water, to avoid the development of pathogenic microorganisms at the cut spots. Defoliation was unnecessary since the plants were young and suffered a natural defoliation. Thereby, one day after pruning, a product was applied on the swollen buds to break dormancy, such as hydrogenated cyanamide $0.6 \%$ (Dormex ${ }^{\circledR}$ ) and mineral oil 1.0\% (Assist $\left.{ }^{\circledR}\right)$; all plants were sprayed until fully wet (i.e. $2.5 \%$ spray solution per plant).

\section{Sample collection and preparation}

The samples of the aerial part were taken from woody tissue in the branches, which were six months old, at $10 \mathrm{~cm}$ depth. Therein, leaves were harvested apart. The sample size of the branches ranged from 10 to $15 \mathrm{~cm}$; branches were taken from all four limbs of the plant. The roots samples $(10-20 \mathrm{~cm}$ height and $10 \mathrm{~cm}$ diameter) were taken at $20 \mathrm{~cm}$ soil depth and $40 \mathrm{~cm}$ away from the base of the tree trunks. A sample of four fruits per plant was measured when the content of soluble solid reached $10^{\circ}$ Brix. In the greenhouse, roots, branches, leaves and fruits samples were washed. In the laboratory, they were taken to dry into forced-air-circulation oven at $65^{\circ} \mathrm{C}$.

\section{Determination of carbohydrate levels}

After collecting all the samples, $\mathrm{CHO}$ levels (SS: fructose + glucose; SC: non-reducing sugar; TS and ST) were determined according to the methodology described by Nelson (1944). TS levels were determined by accurately weighed $1 \mathrm{~g}$ of sample into an Erlenmeyer flask, with $50 \mathrm{ml}$ of distilled water and $6 \mathrm{ml}$ of $\mathrm{HCl}(0.1 \mathrm{~N})$, then incubating the flask in a water bath at $65^{\circ} \mathrm{C}$ for 30 minutes. Therein, samples were cooled to room temperature; and $1.5 \mathrm{~mL}$ of sodium carbonate was required to neutralize the concentration. Samples were filtered; and dilutions were done. Apart, aliquots were prepared to test-tubes by using $1 \mathrm{~mL}$ of the diluted sample with $1 \mathrm{~mL}$ of Nelson-Somogyi. The test-tubes were placed in a water bath for 10 minutes; after cooled to room temperature, added $1 \mathrm{~mL}$ of NelsonSomogyi and $7 \mathrm{~mL}$ of distilled water. Then, samples were homogenized in Vortex tumble stirrer; and the absorbance of the solution was read at $535 \mathrm{~nm}$ by a spectrophotometer. The SS levels (glucose + fructose) were determined by the same sample amount. After weighing, volume increased in a 100 $\mathrm{mL}$ volumetric flask using distilled water, being filtered afterwards. Then, volume also increased in a $100 \mathrm{~mL}$ flask for each organ (root, branches and leaves), when collected $20 \mathrm{ml}$ of root and branches; and $10 \mathrm{ml}$ of leaves. Therefore, $1 \mathrm{ml}$ of the sample was collected in a test-tube; being performed the 
same procedure for TS with $7 \mathrm{~mL}$ of Somogyi-Nelson and 7 $\mathrm{ml}$ of distilled water, and the absorbance of the solution was read at $535 \mathrm{~nm}$. However, to determine the SC levels, TS values were subtracted from the values of SS, then it was multiplied by the correction factor (0.95), according to the aforementioned methodology. Finally, to determine ST levels, the same steps were used to measure the TS levels. But, after adding $\mathrm{HCl}$, samples were autoclaved at $1.00 \mathrm{~atm}$ for 15 minutes. After filtered, $4 \mathrm{~mL}$ aliquots were used for branches and leaves; and $3 \mathrm{ml}$ aliquot for root. All results were expressed in $\mathrm{mg} 100 \mathrm{ml}^{-1}$.

\section{Statistical analysis}

Results were subjected to analysis of variance; means from treatment were compared by Tukey test at $5 \%$ significance. The software SISVAR was used for the analysis of variance (Ferreira, 2011).

\section{Conclusion}

During the peach tree phenological cycle, there were significant variations in $\mathrm{CHO}$ contents in roots, leaves and branches of the two year old 'Douradão' peach. In peaches, ST was the most common form of $\mathrm{CHO}$ stored in all evaluated organs; ST content described in May, could also be extended until June, when pruning begins. Natural target pruning decreased $\mathrm{CHO}$ contents of the aerial parts, which required root storage; consequently, enabled poor quality fruits and lower production.

\section{Acknowledgements}

The authors would thank to the Coordination for the Improvement of Higher Education Personnel (CAPES) to scholarship granted for the first and fifth authors; and to National Council for Scientific and Technological Development (CNPq) to scholarship granted for the third author.

\section{References}

Araújo JPC, Rodrigues A, Scarpare Filho JA, Pio R (2008) Influence of the renewal pruning and control of the rust in the carbohydrate reserves and production of precocious peach tree. Rev Bras Frutic. 30(2): 331-335.

Atkinson RG, Macrae EA (2007) Kiwifruit. In: Pua EC, Davey MR (ed) Transgenic Crops V. Springer Berlin Heiderberg. 60: 329-346.

Barbosa W, Ojima M, Campo Dall'Orto FA (2000) Pêssego 'Douradão'. In: DONADIO, L. C. (Ed.) Novas variedades brasileiras de frutas. Sociedade Brasileira de Fruticultura. 1: 176-177.

Boldingh H, Smith GS, Klages K (2000) Seasonal concentrations of non-structural carbohydrates of five Actinidia species in fruit, leaf and fine root tissue. Ann Bot-London. 85: 469-476.

Borba MRC, Scarpare Filho JA, Kluge RA (2005) Teores de carboidratos em pessegueiro submetidos a diferentes intensidades de poda verde em clima tropical. Rev Bras Frutic. 27(1): 68-72.

Carvalho RIN, Zanette F (2004) Conteúdo de carboidratos em gemas e ramos de macieira durante o outono e inverno em região de baixa ocorrência de frio. Rev Bras Frutic. 26(2): 202205.

Charkazi F, Ramezanpour S, Soltanloo H (2010) Expression pattern of two sugar transporter genes (SuT4 and SuT5) under salt stress in wheat. Plant Omics Journal. 3(6): 194-198.

Chitarra MIF, Chitarra AB (2005) Pós-colheita de frutas e hortaliças: fisiologia e Manuseio. Editora UFLA. 783p.
Chitarra MIF, Carvalho VD (1985) Frutos temperados: pêssegos, ameixas e figos. Informe Agropecuário. 11(125): 56-66.

Cunha AR, Martins D (2009) Classificação climática para os municípios de Botucatu e São Manuel, SP. Irriga. 4(1): 1-11.

Faust M (1989) Physiology of temperature zone fruit trees. New York: John Wiley. 338p.

Ferreira DF (2011) Sisvar: a computer statistical analysis system. Cienc Agrotec. 35(6): 1039-1042.

Flore JA, Layne DR (1996) Prunus. In: Zamski E, Schaffer AA Photoassimilate distribution in plants and crops: source-sink relationships. New York: Marcel Dekker. 1: 825-849.

Hasaneen MNA, Younis ME (2009) Salinity-biofertility interactive effects on growth, carbohydrates and photosynthetic efficiency of lactuca sativa. Plant Omics Journal. 2(2): 60-69.

Hidalgo L (1993) Tratado de viticultura general. Madrid: MundiPrensa. $983 \mathrm{p}$.

Hua SJ, Wang XD, Yuan SN, Shao MY, Zhao XQ, Zhu SJ, Jiang LX (2007) Characterization of pigmentation and cellulose synthesis in colored cotton fiber. Crop Sci. 47: 1540-1546.

Jordan RB, Walton EF, Klages KU, Seelye RJ (2000) Postharvest fruit density as an indicator of dry matter and ripened soluble solids of kiwifruit. Postharvest Biol Tec. 20: 163-173.

Leonel S, Pierozzi CG, Tecchio MA (2011) Production and fruit quality of peach and nectarine trees in subtorrid climate of the state of São Paulo. Rev Bras Frutic.33: 118-128.

Li XH, Park NI, Park CH, Kim SG, Lee SY, Park SU (2011) Influcence of sucrose on rutin content and flavonoid biosynthetic gene expression in seedlings of common buckwheat (Fagopyrum esculentum Moench). Plant Omics Journal. 4: 215-219

Marafon AC, Bacarin M, A, Rodrigues AC,Verissimo V (2007) Concentrações de carboidratos em tecidos de pessegueiro (Prunus persica (L.) Batsch) cv. Jubileu em plantas com e sem sintomas de morte-precoce durante o período de dormência. Rev Bras Frutic. 29(1): 75-79.

Mehouachi J (2009) Delay of early fruitlet abscisión by Branco girdlin in Citrus coincides with previous increases in carbohydrate and gibberelin concentrations. Plant Growth Regul. 58: 15-23.

Nelson N (1944) A photometric adaptation of Somogi method for determination of glicose. J Biol Chem. 153: 375-380.

Noguchi A, Horikawa M, Fukui Y, Fukuchi-Mizutani M, IuchiOkada A, Ishiguro M, Kiso Y, Nakayama T, Ono E (2009) Local differentiation of sugar donor specificity of flavonoid glycosyl transferase in lamiales. Plant Cell. 21: 1556-1572.

Pedro Júnior MJ, Barbosa W, Rolim GS, Castro, JL (2007) Época de florescimento e horas de frio para pessegueiros e nectarineiras. Rev Bras Frutic. 29(3): 425-430.

Pereira CS, Siqueira DL, Salomão LCC, Cecon PR Santos D (2011) Teores de carboidratos nas folhas e produção de limeiras ácida 'Tahiti' aneladas e tratadas om ácido giberélico. Rev Bras Frutic. 33: 706-712.

Petri JL, Palladini LA, Schuck E, Ducroquet JP, Matos CS, Pola AC (1996) Dormência e indução de brotação de fruteiras de clima temperado. EPAGRI. 210p.

Scarpare Filho JA, Kluge RA, Tavares S (2003) A cultura do pessegueiro: recomendações para o cultivo em regiões subtropicais. Piracicaba: editora ESALQ. 48p. 